EGU2020-18358

https://doi.org/10.5194/egusphere-egu2020-18358

EGU General Assembly 2020

(c) Author(s) 2021. This work is distributed under

the Creative Commons Attribution 4.0 License.

\title{
Paleotemperature and paleosalinity evolution across Eocene- Oligocene Transition in North Atlantic Ocean: Insights from geochemical analysis of bivalve shells.
}

\author{
Justine Briard ${ }^{1,2}$, Marc de Rafélis ${ }^{1}$, Emmanuelle Vennin ${ }^{2}$, Mathieu Daëron ${ }^{3}$, Valérie Chavagnac ${ }^{1}$, \\ Laurent Emmanuel ${ }^{4}$, Didier Merle ${ }^{5}$, and Emmanuelle Pucéat ${ }^{2}$ \\ ${ }^{1}$ Géosciences Environnement Toulouse (GET), Université de Toulouse, France (justine.briard@u-bourgogne.fr) \\ ${ }^{2}$ Biogéosciences, Université Bourgogne Franche-Comté, France \\ ${ }^{3}$ Laboratoire des Sciences du Climat et de l'Environnement, Université Paris-Saclay, France \\ ${ }^{4}$ Institut des Sciences de la Terre Paris (ISTeP), Sorbonne Université, France \\ ${ }^{5}$ Muséum National d'Histoire Naturelle, Sorbonne Université, France
}

The Cenozoic period encompasses the last transition from the "greenhouse" climate of the late Early Eocene ( $\sim 50 \mathrm{Ma}$ ) to our modern "icehouse" climate with its much lower $\mathrm{CO}_{2}$ levels, significant polar glaciation and major sea level drop. The Eocene-Oligocene transition (EOT), that marks the first major ice-sheet build-up on Antarctica, has been extensively studied as it represents the entrance into an icehouse mode. Identification of this major step of Antarctic ice-sheet build-up strongly relies on $\delta^{18} \mathrm{O}$ and $\mathrm{Mg} / \mathrm{Ca}$ benthic foraminifera records from ODP / DSDP sites. By contrast, few records currently exist from coastal environments despite the presence of abundant fossil archives, like bivalve shells. Yet palaeoenvironmental records from these peculiar coastal sites could bring information on how they react to global climate changes and help to further understand the behavior of our climate system. In this study, we applied a multi-proxy strategy coupling $\delta^{18} \mathrm{O}, \delta^{13} \mathrm{C}$, clumped isotopes $\left(\Delta_{47}\right)$, strontium isotopes $\left({ }^{87} \mathrm{Sr} /{ }^{86} \mathrm{Sr}\right)$ analyses on aragonitic and calcitic bivalves and sediments recovered from the Isle of Wight (London-Paris Basin, Northeastern Atlantic Ocean) to provide additional constrain on environmental changes in this region across the Eocene-Oligocene Transition ( 37.8-33 Ma).

Our new coupled $\delta^{18} \mathrm{O}$ and $\Delta_{47}$ dataset highlights a marked decrease in local seawater temperatures $\left(\sim 8^{\circ} \mathrm{C}\right)$ coupled to a drop in local seawater $\delta^{18} \mathrm{O}$, likely linked to the sea level drop associated with ice-cap formation and an evolution toward more proximal, brackish environment in this region (that is apparent from sediment facies evolution). We estimate the salinity decrease recorded at the local scale from the Eocene to the Oligocene as reaching about 6 PSU, from 31 to 25 PSU. Strontium isotope analyses of the bivalves support this interpretation, showing values close to that of seawater up to the EOT but a marked deviation from contemporaneous global seawater ${ }^{87} \mathrm{Sr} /{ }^{86} \mathrm{Sr}$ values toward more radiogenic values afterward. This positive deviation is in agreement with an evolution toward more proximal environments, subjected to larger freshwater inputs. 